\title{
The effect of Puerariae radix on lipoprotein metabolism in liver and intestinal cells Jeong-Sook Lee ${ }^{1}$, John Mamo ${ }^{2}$, Nerissa $\mathrm{Ho}^{2}$ and Sebely Pal*2
}

\author{
Address: ${ }^{1}$ Department of Food and Nutrition, Kosin University, Pusan 6660-701, Korea and ${ }^{2}$ Department of Nutrition, Dietetics and Food \\ Sciences, Curtin University, Perth, Western Australia, Australia \\ Email: Jeong-Sook Lee - jslee@kosin.ac.kr; John Mamo - j.mamo@curtin.edu.au; Nerissa Ho - n.ho@curtin.edu.au; \\ Sebely Pal* - s.pal@curtin.edu.au \\ * Corresponding author
}

Published: 16 December 2002

BMC Complementary and Alternative Medicine 2002, 2:12
Received: 19 September 2002

Accepted: 16 December 2002

This article is available from: http://www.biomedcentral.com/1472-6882/2/12

(C) 2002 Lee et al; licensee BioMed Central Ltd. This is an Open Access article: verbatim copying and redistribution of this article are permitted in all media for any purpose, provided this notice is preserved along with the article's original URL.

\begin{abstract}
Background: Animal studies investigating the beneficial effects of Puerariae radix on cardiovascular disease have suggested this plant possesses anti-diabetic and lipid lowering properties. However, the exact mechanism by which Puerariae radix affects lipid metabolism is currently unknown. The aim of this study was to investigate the effect of the water extract of Puerariae radix on the secretion of VLDL and chylomicrons from HepG2 liver cells and $\mathrm{CaCo} 2$ cells, respectively, in humans.

Methods: The amount of apoBI00 (a protein marker for VLDL) and apoB48 (a protein marker for chylomicrons) in cells and media were quantified by Western Blotting and enhanced chemiluminescence $(\mathrm{ECL})$. Total, free and esterified cholesterol concentrations were measured by gas liquid chromatography.

Results: Treatment of cells with water extract of Puerariae radix significantly decreased apoB 100 production and secretion from HepG2 cells up to $66 \%$ in a dose dependent manner. The intracellular total cholesterol and free cholesterol concentration in HepG2 cells also decreased with increasing concentration of the Puerariae radix. In contrast, water extract of Puerariae radix attenuated apoB48 concentrations in cells, but not apoB48 secretion from $\mathrm{CaCo} 2$ enterocytes.

Conclusions: Collectively, our findings suggest that the water extract of Puerariae radix attenuates the hepatic lipoprotein production and secretion. Our present cell culture findings may explain why circulating VLDL and LDL levels were attenuated in animals supplemented with Puerariae radix. Since decreasing the production and secretion of atherogenic lipoproteins decreases the risk of development of cardiovascular disease, diets supplemented with radix may provide a safe and effective beneficial cardioprotective effects in humans.
\end{abstract}

\section{Background}

Central to the pathology of coronary heart disease is the accumulation of cholesterol within the intima of arterial blood vessels. There is considerable evidence implicating low density lipoprotein (LDL) as a primary source of plaque cholesterol. There is now an accumulating body of evidence which suggests that remnants of postprandial lipoproteins, such as chylomicrons, may be atherogenic when their concentrations in plasma is chronically elevated [1-3]. Apolipoprotein B48 (apoB48) is a structural 
protein moiety residing on the surface of chylomicrons, and is necessary for the synthesis and secretion of this intestinal lipoprotein. Whereas, apolipoprotein B100 (apoB100) is exclusively synthesised by the liver and is the principal constituent of very low density lipoprotein (VLDL), the precursor of LDL [4]. In general, apoB containing lipoproteins are associated with increased atherosclerotic risk. Current therapeutic interventions focus on reducing the plasma concentration of LDL and chylomicron remnants by decreasing their production and also by promoting clearance from plasma by the hepatic LDL receptor [5]. Specific therapeutic strategies include improved dietary habits, lifestyle changes, and/or powerful lipid lowering drugs. In this study, we examined the effects of Puerariae radix, a putative hypolipidaemic agent, on VLDL and chylomicron production from liver and intestinal cells.

Many epidemiological studies have shown that diet rich in fruits and vegetables can protect against the development of cardiovascular disease [6,7]. Researchers have examined the composition of these foods, and identified the physiologically active components as phytochemicals (non-nutritive substances in plants that possess healthprotective effects). Plant phytochemicals are categorised into plant sterols, flavonoids, and plant sulfur compounds. A large number of studies have demonstrated the beneficial effects of flavonoid consumption against the development of cancer and cardiovascular disease [6-8]. Pueraria Lobata is a traditional oriental medicinal plant (also grown in the US) which is rich in flavonoids. The root of this plant, Puerariae radix is especially rich in the isoflavones (a class of flavonoids), such as daidzein, daidzin, puerarin, genistein and daidzein-4',7-diglucoside $[9,10]$. Puerariae radix is widely used to cure alcoholism, hypertension, common colds, influenza, menopause and improve vascular activities [11-13]. The health-food industry is claiming that Puerariae radix is a health promoting herb and advocating taking pure "radix" pills. There appears to be many claims about the Puerariae radix without strong scientific evidence supporting that it has beneficial effects.

We have recently demonstrated that Puerariae radix has potential anti-diabetic and lipid lowering properties in animals [14]. Significant lipid lowering effects were observed in rats when they were supplemented with Puerariae radix (water extract) in association with a high fat-high cholesterol diet compared to control rats [14]. VLDL and LDL cholesterol levels were significantly decreased in rats fed the water extract of Puerariae radix. However, the exact mechanism by which Puerariae radix affects lipid metabolism is currently unknown. The aim of this study was to investigate whether Kudzu decreases the production of hepatic and intestinal lipoproteins in humans. HepG2 liv- er cells and $\mathrm{CaCo} 2$ intestinal enterocytes represent two cell culture model systems which show morphological and biochemical properties consistent with hepatic cells and fully differentiated small intestinal enterocytes, respectively. In this study, cells were incubated with the water extract of Kudzu and the secretion of apoB100 (a protein marker for VLDL) from HepG2 liver cells and apoB48 (a protein marker for chylomicrons) from Caco2 cells was quantified.

\section{Methods}

The human transformed colonic epithelial CaCo2 cells and HepG2 cells were purchased from ATCC (American Type Culture Collection). Cell culture media, reagents and fetal bovine serum (certified grade) were from Gibco BRL Life Technologies, Gaithsburg, MD, USA. Costar transwell, polycarbonate microporous cell culture inserts and flasks for tissue culture were obtained from Corning, Cambridge, MA. Bis-(trimethylsilyl)-trifluoroacetimide (BSTFA) and bicinchoninic acid (BCA) protein assay reagents were obtained from Pierce, Rockford, Illinois. Benzamidine, PMSF, 25-hydroxycholesterol, 5 $\alpha$-cholestane, Triton X-100 and other common laboratory reagents were from Sigma Chemical Co, St. Louise, USA. Polyvinylidene fluoride (PVDF) membrane was from Millipore Corporation, Bedford MA. Ultrapure electrophoresis reagents were from Bio-Rad Laboratories, Richmond, USA. Enhanced chemiluminescence detection reagents, hyper-film ECL, and rabbit anti-donkey IgG, were purchased from Amersham International, England. Rabbit anti-human apoB antibody was purchased from DAKO A/S Denmark.

\section{Preparation of Water extract of Puerariae radix}

Puerariae radix (100 g) was dried, chopped and extracted in $500 \mathrm{ml}$ of boiling water for $4 \mathrm{~h}$. After filteration, the extract was concentrated with a vacuum rotary evaporator and freeze-dried. Water extract solutions was prepared freshly prepared daily by adding the required grams of the freezed dried extract of Puerariae radix in $100 \mathrm{ml}$ hot water to make a $\mathrm{mg} / \mathrm{ml}$ solution.

\section{HepG2 cell culture}

Human cell line HepG2 cells were grown under 5\% CO2 at $37^{\circ} \mathrm{C}$ in Dulbecco's modified Eagle's media (DMEM) containing $10 \%(\mathrm{v} / \mathrm{v})$ fetal calf serum (v/v) and $1 \%$ penicillin-streptomycin-glutamine [15]. Cells were grown in $175 \mathrm{~cm}^{2}$ flasks containing DMEM supplemented with $10 \%$ FCS until confluent. Cells were then subcultured at 5 $\times 105$ cells into $25 \mathrm{~cm}^{2}$ flasks containing the same media. Cells were preincubated in serum free medium supplemented with $1 \%$ bovine serum albumin (BSA) then incubated for $24 \mathrm{~h}$ in the various amounts $(0-0.44 \mathrm{mg} / \mathrm{ml})$ of water extract of Puerariae radix. 


\section{CaCo2 cell culture}

Human epithelial $\mathrm{CaCo} 2$ cells were grown at $37^{\circ} \mathrm{C}$ in DMEM with $20 \%$ fetal calf serum (v/v), $2 \%$ penicillinstreptomycin-glutamine and 1\% non-essential amino acids. Cells were seeded at a density of $1 \times 10^{6}$ in $75 \mathrm{~cm}^{2}$ flasks [16]. The media was replaced every 2 days. Cells were subcultured from flasks at $90 \%$ confluency, to polycarbonate microporous membranes $(0.4 \mathrm{um}$ pore size, inserts of $24.5 \mathrm{~mm}$ diameter) and plated at a density of $2 \times$ $10^{4}$ cells $/ 6.5 \mathrm{~mm}$ diameter filter. Fully differentiated $\mathrm{CaCo} 2$ cells were used for all experiments (13 days postsubculturing). Cells were incubated for $24 \mathrm{~h}$ in different amount of water extract of Puerariae radix and DMEM supplemented with $2 \%$ penicillin-streptomycinglutamine and 1\% non-essential amino acids. 'Treatment' media was added to the apical well after washing the cells with phosphate buffered saline (PBS).

\section{Cell isolation}

HepG2 and CaCo2 cells were washed, harvested and resuspended in PBS following the $24 \mathrm{~h}$ incubation period with the 'treatment' media. An aliquot of cells was used to determine free and total cholesterol by Gas liquid Chromatography (GLC) [15] and another small aliquot was used to measure cell protein using an enhanced bicinchoninic acid procedure [15]. The remaining cells were solubilised in buffer (3\% Triton X-100 in PBS with $1 \mathrm{mM}$ benzamidine, and $1 \mathrm{mM}$ PMSF) at $4^{\circ} \mathrm{C}$ for $18 \mathrm{~h}$. Samples were pelleted at $400 \times \mathrm{g}$ for $5 \mathrm{~min}$ at $4^{\circ} \mathrm{C}$, the supernatant collected and the cell debris discarded. The supernatant was used to measure apoB100 and apoB48 by Western blot and enhanced chemiluminscence (ECL) $[15,16]$. A small aliquot of the supernatant was used to measure solubilised protein.

The media from HepG2 cells and the basolateral well from $\mathrm{CaCo} 2$ cells was measured and kept on ice. Aliquots of media was used to measure apoB100and apo B48 by Western blots and ECL.

\section{Sterol quantitation}

Lipid was extracted from solubilised CaCo-2 and HepG2 cells for the analysis of free cholesterol using a modified method of Folch et al. [17]. Briefly, $1 \mathrm{ml}$ of chloroform ( $\mathrm{CHCl} 3)$ was added to cells along with internal standard ( $5 \alpha$-cholestane) and $25 \mu$ l of saturated salt solution to prevent the formation of a fatty acid emulsion. Samples were mixed thoroughly and centrifuged at $200 \times \mathrm{g}$ for 10 min. The top aqueous layer was aspirated and discarded and the lower chloroform layer dried under a stream of $\mathrm{N} 2$. Samples were reconstituted in hexane before GC analysis.

To measure total cholesterol in the cells, $1 \mathrm{ml}$ of $1 \mathrm{M} \mathrm{KOH}$ in methanol was added to an aliquot of cells to saponify cholesterol esters. The tubes were then flushed with N2 and heated at $45^{\circ} \mathrm{C}$ for $1 \mathrm{~h}$. After hydrolysis was complete, the solution was diluted with $2 \mathrm{ml}$ of water, internal standard was added, and the lipids were extracted twice with hexane $(1 \mathrm{ml})$.

Free and total cholesterol were determined by comparison of peak area with a five point external calibration curve. An internal standard was used to correct for injection volume $(1 \mathrm{uL})$ variability. Calibration was performed daily. A Perkin Elmer Autosystem XL gas chromatograph fitted with a ZB-1 dimethyl polysiloxane column (30 m $\times 530$ $\mu \mathrm{m}, 1.5 \mu \mathrm{m}$ film thickness, Phenomenex) and splitless injector was used with helium as the carrier gas at a flow rate of $6.0 \mathrm{~mL} / \mathrm{min}$. An estimate of esterified cholesterol was derived as the difference between total and free cholesterol.

\section{Apo B 100 and Apo B48 Quantitation}

Solubilised cell protein $(100 \mu \mathrm{g})$, rainbow molecular weight-markers and purified apo B100 and apo B48 standards (previously prepared according to Zilversmit and Shea [18] were separated by SDS-PAGE using precast NuPAGE 3-8\% gradient gels in a Novex Mini-Cell (Novex Instruments, CA, USA) at $150 \mathrm{~V}$ for $1 \mathrm{~h}$. Separated proteins were electrotransferred at $30 \mathrm{~V}$ for $90 \mathrm{~min}$ onto 0.45 $\mu \mathrm{m}$ polyvinylidene fluoride (PVDF) membrane. The membranes were blocked for $1 \mathrm{~h}$ at $25^{\circ} \mathrm{C}$ in TBST ( $10 \mathrm{mM}$ Tris-HCL buffer, pH 7.4, containing $154 \mathrm{mM} \mathrm{NaCl}$ ) and $10 \%(\mathrm{w} / \mathrm{v})$ skim milk powder. After washing in TBST, the membranes were incubated with $5.0 \mu \mathrm{g} / \mathrm{ml}$ apoB antibody (DAKO apo B rabbit anti-human). The membranes were incubated with $0.5 \mu \mathrm{g} / \mathrm{ml}$ donkey anti-rabbit IgG linked to horseradish peroxidase in TBST and subsequently washed twice with TBST. Membranes were incubated with enhanced chemiluminescence substrate solution for detection of horseradish and exposed to hyper-film ECL. Films were scanned to determine the intensity of the apoB48 protein bands using a UMAX Vista S6E Flatbed Scanner and the intensity of the apoB and was quantitied using the computer program Scion Image (Scion Incorporation). Bands of interest were compared against purified apoB protein standard of known mass. The mean intraand inter-assay coefficient of variance for apo B were each less than 4\%. Experiments were done in duplicate and repeated 3-4 times on separate occasions.

\section{Statistical Analysis}

Statistical analysis was carried out using SPSS for version 10.0.7 (SPSS Incorp). Means were compared using oneway analysis of variance (ANOVA) followed by Tukey's post-hoc test. All means were compared to each other, means with different letters above bar graphs indicate significant differences at $\mathrm{p}<0.05$. 


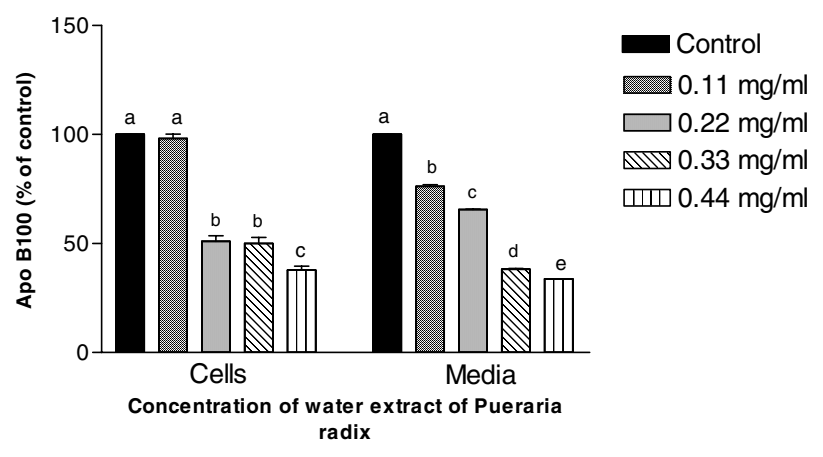

Figure I

The effect of Puerariae radix water extract on Apo B I 00 production and secretion in HepG2 cells. HepG2 cells were incubated with water extraction on Puerariae radix for $24 \mathrm{~h}$. ApoB 100 concentration in the cells and media were quantified and expressed as a percentage of control \pm SEM $(n=4)$. Means were compared using one-way analysis of variance (ANOVA) followed by Tukey's post-hoc test. Different letters above bar graphs indicate significance from each other at $p<0.05$.

\section{Results}

The effect of water extract of Puerariae radix on apoB 100 production and secretion from HepG2 cells

The effect of water extract of Puerariae radix on apoB100 production in HepG2 cells was investigated. Cells were incubated with $0-0.44 \mathrm{mg} / \mathrm{ml}$ water extract of Puerariae radix for 24 hours, and the apoB100 content in cells, as well as the amount of apoB100 secreted into culture medium, were determined. Figure 1 shows that cells incubated with $0.44 \mathrm{mg} / \mathrm{ml}$ water extract of Puerariae radix resulted in up to a $62 \%$ decrease in apoB100 levels in HepG2 cells compared to control cells. Similarly, secretion of apoB100 from cells significantly decreased when incubated with the water extract of Puerariae radix. Apolipoprotein B100 concentrations in the media decreased up to $66.2 \%$ when incubated with $0.44 \mathrm{mg} / \mathrm{ml}$ of the extract. Cell viability was determined using the Trypan Blue exclusion test. There was no difference in cell viability between control cells and cells treated with water extract of Puerariae radix (data not shown).

The effect of water extract of Puerariae radix on cholesterol content in HepG2 cells

The effect of water extract of Puerariae radix on cholesterol metabolism in HepG2 cells was determined by GLC analysis. Treatment of the cells with water extract of Puerariae radix significantly decreased the intracellular total and free cholesterol levels (Fig 2). The free and total cholester-

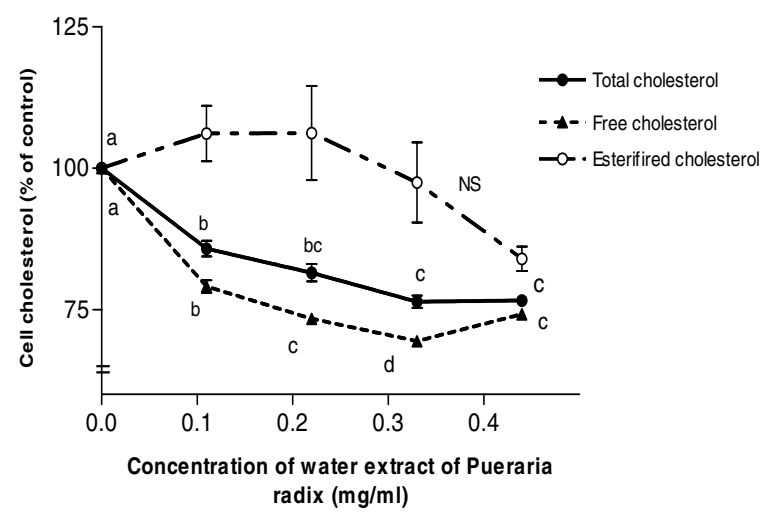

Figure 2

The effect of water extract of Puerariae radix on intracellular total, free and esterified cholesterol concentrations in HepG2 cells. Hep G2 cells were incubated with water extract of Puerariae radix for $24 \mathrm{~h}$. Total, free and esterified cholesterol levels were quantified by GLC and expressed as a percentage of control \pm SEM $(n=3)$. Means were compared using one-way analysis of variance (ANOVA) followed by Tukey's post-hoc test. Different letters in graphs indicate significance from each other at $p<$ 0.05 . NS: not significant at $p>0.05$

ol content were lowest in cells when incubated with concentrations greater than $0.22 \mathrm{mg} / \mathrm{ml}$ of Puerariae radix extract. Incubation of cells with Puerariae radix also decreased the intracellular concentration of cholesterol ester, but this effect was only significant at the highest dose of $0.44 \mathrm{mg} / \mathrm{ml}$.

The effect of water extract of Puerariae radix on Apolipoprotein $\mathrm{B} 48$ production and secretion in $\mathrm{CaCo2}$ cells

Cells were incubated with $0-0.44 \mathrm{mg} / \mathrm{ml}$ Puerariae radix water extract for $24 \mathrm{~h}$, and the apoB48 content in these cells and in culture medium was determined. The apoB48 concentration in the cells was significantly decreased by $25 \%$ when incubated with $0.33 \mathrm{mg} / \mathrm{ml}$ and $0.44 \mathrm{mg} / \mathrm{ml}$ of water extract of Puerariae radix compared with control cells (Figure 3 ). However, there was no significant difference on apoB48 levels in the media incubated with the water extract.

\section{The effect of water extract of Puerariae radix on choles- terol content in $\mathrm{CaCo2}$ cells}

The effect of water extract of Puerariae radix on cholesterol content in $\mathrm{CaCo} 2$ cells was determined using GLC. Total cholesterol and esterified cholesterol in the cells significantly decreased with water extract of Puerariae radix concentrations of greater than $0.22 \mathrm{mg} / \mathrm{ml}$ compared to 


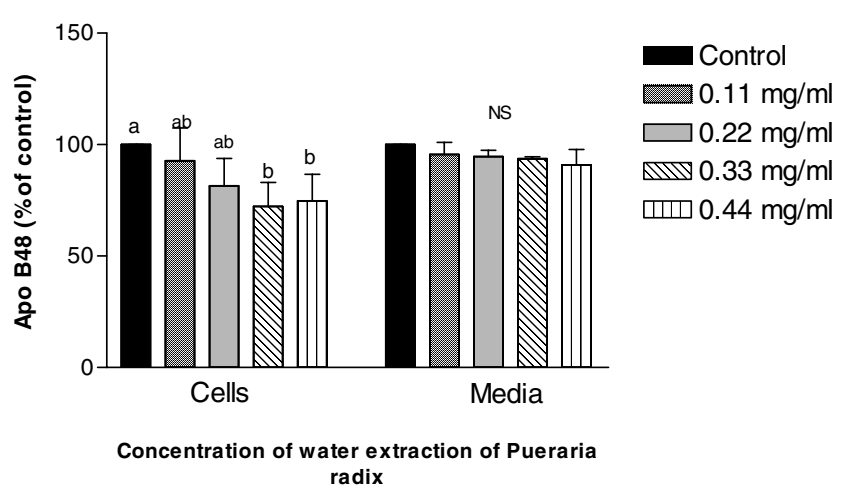

Figure 3

The effect of Puerariae radix water extract on apoB48 production and secretion in $\mathrm{CaCo} 2$ cells. $\mathrm{CaCo} 2$ cells were incubated with water extract of Puerariae radix for 24 . ApoB48 concentration in the cells and media were quantified and expressed as a percentage of control \pm $\operatorname{SEM}(n=3)$. Means were compared using one-way analysis of variance (ANOVA) followed by Tukey's post-hoc test. Different letters above bar graphs indicate significance from each other at $p<0.05$. NS: Not significant at $p>0.05$.

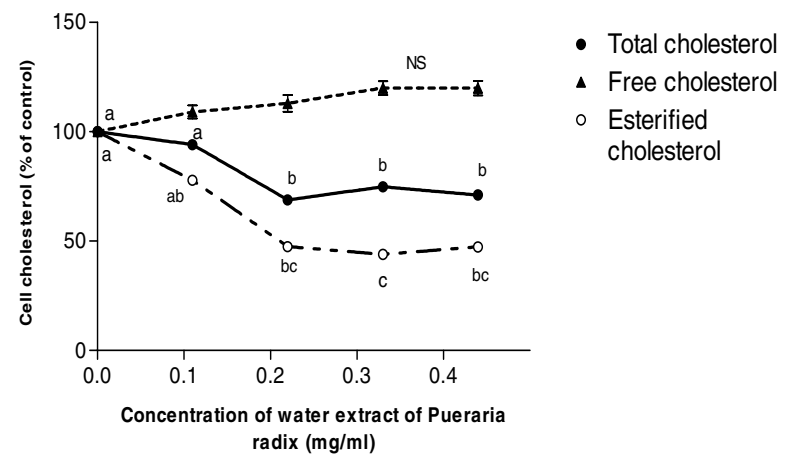

Figure 4

The effect of water extract of Puerariae radix on intracellular total cholesterol, free cholesterol and esterified cholesterol concentrations. $\mathrm{CaCo} 2$ cells were incubated with water extract of Puerariae radix for 24 h. Total, free and esterified cholesterol levels in the cells are expressed as a percentage of control $\pm \operatorname{SEM}(n=3)$. Means were compared using one-way analysis of variance (ANOVA) followed by Tukey's post-hoc test. Different letters in graphs indicate significance at $p<0.05$. NS: not significant at $p>0.05$ control cells (Fig 4). There was no significant difference in the concentration of free cholesterol within the cells incubated with Kudzu at any concentration.

\section{Discussion}

Previous studies have demonstrated that circulating VLDL and LDL cholesterol levels significantly decreased in rats consuming a high fat diet supplemented with $5 \%$ Puerariae radix of water extract [14]. These results suggest that Puerariae radix (Kudzu) either attenuates the production and secretion of these lipoproteins or that it increases their clearance from circulation. To explore the former, we examined the effect of the water extract of Puerariae radix on secretion of apoB100 from HepG2 liver cells and apoB48 from $\mathrm{CaCo} 2$ cells. Treatment of HepG2 cells with increasing concentrations of Kudzu water extract significantly decreased the amount of apoB100 in the cells and media. Concomitantly, total and free cholesterol levels in the cells also significantly decreased. Water extract of Puerariae radix also decreased the intracellular concentration of esterified cholesterol but this effect was only significant at higher doses of $0.44 \mathrm{mg} / \mathrm{ml}$. Our findings in cell culture suggest that Kudzu may potentially attenuate the circulating levels LDL in animals by regulating the secretion of the precursor lipoprotein, VLDL. The decrease in intracellular cholesterol metabolism may be the mechanism by which VLDL secretion is decreased in liver cells.

Our results suggest that decreased cholesterol availability in the presence of Kudzu may decrease the secretion of apoB100 from hepatocytes. ApoB100 is mainly synthesized and secreted by hepatocytes as VLDL before it is converted to LDL in circulation [4]. The formation of hepatic apoB100 containing lipoprotein particles is a complex process that requires the coordinate synthesis and assembly of apoB100, triglyceride (TG), cholesterol esters (CE), phospholipids and other components [4]. It is believed that apoB100 secretion is primarily regulated post-translationally as apoB 100 production rates are directly correlated to the fraction of newly synthesised apoB100 that escapes intracellular degradation during translocation across the ER [4]. It is the availability of lipid which seems to influence the proportion of newly synthesised apoB100 that is degraded $[19,20]$. However, it is unclear whether the regulation exclusively involves triglyceride, cholesterol, cholesterol ester, phospholipids or, a combination of these. Many in vitro [21-23] and in vivo $[24,25]$ studies have reported the importance of cholesterol and cholesterol ester in the control of apoB100. Cell cultures studies have shown that if cholesterol availability is limited by introducing an HMG-CoA inhibitor (the rate limiting enzyme in cholesterol synthesis), then apoB100 secretion will also be attenuated $[25,26]$. For example, we have demonstrated that atorvastatin (an HMG-CoA inhibitor) decreased apoB100 production and secretion from liver 
cells by inhibiting cholesterol biogenesis [27]. In addition, we have also recently demonstrated that green tea catechins [28], and red wine polyphenolics [28] attenuated apoB100 production and secretion from liver cells by inhibiting the cholesterol biosynthesis pathway in a similar manner to atorvastatin. Our findings herein also demonstrate that Kudzu water extract significantly suppressed intracellular cholesterol production (Figure 2), suggesting that this compound(s) may act in a similar manner to HMG-CoA reductase inhibitors to attenuate the secretion of apoB100 from liver cells.

In contrast to the results observed in HepG2 cells, apoB48 was not significantly decreased from $\mathrm{CaCo} 2$ cells when incubated with increasing concentrations of the Kudzu water extract. Treatment of cells with water extract of Puerariae radix significantly decreased the intracellular total cholesterol concentration with increasing concentrations of the extract, but did not affect free cholesterol levels in the cells. Water extract of Puerariae radix also decreased the intracellular concentration of esterified cholesterol, but this effect was only significant at doses greater than $1 \%$. The reason why Puerariae radix affected apoB48 production, not affected apoB48 secretion is unknown. However, we have previously shown that suppression of cholesterol biosynthesis with atorvastatin (an HMG-CoA reductase inhibitor) under stimulatory conditions accelerated the degradation of apoB48 in $\mathrm{CaCo} 2$ cells without affecting its secretion [16].

In humans, apoB48 is associated with chylomicrons and chylomicron remnants, and is synthesised by the intestine [29]. After ingesting a fat meal, the dietary lipids (triglyceride and cholesterol) are packaged together with apoB48 into a chylomicron particle by the enterocyte [29]. Although, the same regulatory mechanisms have been speculated to be responsible for both forms of apoB, there is a body of evidence that suggests intestinal apoB48 control differs to that of hepatic apoB100. Studies by Paulweber at al [30] have shown that there are distinct differences between the promoter region of apoB genes of hepatic and intestinal cells. Pau et al [31] reported that treatment with $\mathrm{CaCo} 2$ cells with lovastatin had no effect on total apoB48 secretion under basal conditions. Consistent with these findings, our previous studies showed that atorvastatin did affect apoB48 secretion from $\mathrm{CaCo} 2$ cells [16]. In these studies, the addition of exogenous sterols did not stimulate apoB48 secretion from intestinal cells. In contrast, studies in liver cells all demonstrate the importance of endogenous cholesterol synthesis (using HMG-CoA reductase inhibitors) on apoB100 secretion in hepatocytes. Taken together, studies indicate that neither endogenous nor exogenous cholesterol appears to acutely modulate apoB48 secretion from intestinal cells, but does regulate apoB100 secretion from liver cells. Similarly, the effect of
Kudzu on apoB100 secretion from liver cells maybe determined by cholesterol availability, but not in intestinal cells.

Puerariae radix contains high levels of the phytoestrogens (plant-derived substances with weak estrogenic effects), daidzin, daidzein and puerarin, along with other related isoflavones $[9,10,12,32,33]$. These constituents are the basis of Kudzu's therapeutic use for menopause by the Orientals, consuming the crushed root (9-15 grams/ day) prepared as tea $[12,33,34]$. Soy is also an excellent dietary source of these phytoestrogens and thus consumed by many western women to alleviate the many adverse effects of menopause (hot flashes, increases in lipids, blood sugar). Presently, the health-food industry is claiming that the compounds in Puerariae radix decrease symptoms of menopausal and blood lipids, and are therefore promoting the consumption of pills containing several grams of pure Puerariae radix. At present, strong scientific evidence supporting that Kudzu provides such beneficial effects is limited. In this study, we have demonstrated that Puararia radix can decrease lipoprotein production and secretion from the liver cells by affecting cholesterol availability within the cell, similar to lipid lowering drugs. Our present cell culture findings may explain why circulating VLDL and LDL levels were attenuated in animals supplemented with Kudzu [14]. It has been approved that disorders of lipid metabolism result in an increased risk for atherosclerosis and that lowering of LDL-cholesterol and postprandial lipoproteins reduces morbidity and mortality from CHD [5]. Since decreasing the production and secretion of atherogenic lipoproteins decreases the risk of development of cardiovascular disease, diets supplemented with Kudzu may provide an effective beneficial cardioprotective effects in humans. However, further studies in humans are required to examine the bioavailability and the doses of Puerariae radix required to have significant lipid lowering before recommendations can be made.

\section{Competing interests}

None declared.

\section{Authors' contributions}

All authors read and approved the final manuscript. SL participated in the experimental component of the study. $\mathrm{JM}$ - participated in intellectual input on the final draft of the manuscript. NH - participated in the experimental part of the study. SP - participated in the design of the study and performed the statistical analysis, conceived of the study, and participated in its design and coordination and wrote the manuscript.

\section{Acknowledgements}

The financial support of the Australian National Heart Foundation is gratefully acknowledged. 


\section{References}

I. Karpe F, Steiner G, Uffelman K, Olivecrona T and Hamsten A Postprandial lipoproteins and progression of coronary atherosclerosis. Atherosclerosis 1994, 1 06:83-97

2. Meyer E, Westerveld HT, de Ruyter-Meijstek FC, van Greevenbroek MMJ, Rienks R, van Rijn HJM, Erkelens DW and de Bruin TWA Abnormal postprandial $B-48$ and triglyceride responses in normolipidemic women with greater than $70 \%$ stenotic coronary artery disease: a case-control study. Atherosclerosis 1996, I 24:221-235

3. Weintraub MS, Grosskopf I, Rassin T, Miller H, Charach G, Rotmensch $\mathrm{HH}$, Liron M, Rubinstein A and laina A Clearance of chylomicron remnants in normolipidaemic patients with coronary artery disease: case control study over three years. $B M J 1996$, 3 I 2:936-939

4. Boren J, Rustaeus S and Olofsson S-O Studies on the assembly of apolipoprotien B- 100 and B-48 containing very low density lipoprotein in McArdle RH-7777 cells. J Biol Chem 1994, 269:25879-25888

5. Brown MS and Goldstein JL The LDL receptor concept: clinica and therapeutic implications. Bile Acids and Atherosclerosis (Edited by: Grundy S) Raven Press, New York 1988, I 5:85-93

6. Hollman P and Katan MB Dietary Flavonoids: Intake, Health Effects and Bioavailability. Food and Chemical Toxicology 1999 37:937-942

7. Hertog MGL, Kromhout D, Aravanis C, Blackburn H, Buzina R, Fidanza F, Giampaoli S, Jansen A, Menotti A, Nedeljkovic S, Pekkarinen M, Simic B, H Toshima, Feskens EJM, Hollman PCH and Katan MB Flavonoid intake and long-term risk of coronary heart disease and cancer in the Seven Countries Study. Archives of Internal Medicine 1995, I55:381-386

8. Hertog MGL, Feskens EJM, Hollman PCH, Katan MB and Kromhout $D$ Dietary flavonoids and cancer risk in the Zutphen Elderly Study. Nutrition and Cancer 1994, 22:175-184

9. Cao X, Tian Y, Zhang T, Li X and Ito $Y$ Separation and purification of isoflavones from Pueraria lobata by high-speed counter-current chromatography. J Chromatogr 1999, 855:709-7I 3

10. Ohshima Y, Okuyama T, Takahash K, Takizaw T and Shibata S Isolation and high performance liquid chromatography (HPLC) of isoflavonoids from the Pueraria root. Planta Med 1988, 54(3):250-4

II. Keung WM and Vallee BL Kudzu root: an ancient Chinese source of modern anti-dipsotropic agents Phytochemistry 1999 47:499-506

12. Kaufman PB, Duke JA, Brielmann H, Boik J and Hoyt E A comparative survey of leguminous plants as sources of the isoflavones, genistein and daidzein: implications for human nutrition and health. Journal of Alternative and Complementary Medicine 1997, 3:7-12

13. Wang LY, Zhao AP, Chai XS and $S X$ Effects of puerarin on cat vascular smooth muscle in vitro. Pharmacologica Sinica 1994 I5:180-182

14. Lee JS, Lee KH and Jeong JH Effects of Extract of Puerariae radix on lipid metabolism in rats fed high fat diet. I Korean Soc Food Sci Nutr 1999, 28( I):218-224

15. Pal S, Thomson A, Bottema CDK and Roach PD Polyunsaturated fatty acids down regulate the low density lipoprotein receptor of human HepG2 cells. J Nutri Biochem 2002, I 3:55-63

16. Pal S, Allister $\mathrm{E}$ and Mamo $\mathrm{CL}$ Cholesterol esters regulate apoB48 secretion in CaCo2 cells. Atherosclerosis 2002, I 6 I:55-63

17. Folch J, Lees M and Sloane Stanley GM A simple method for the isolation and purification of total lipids from animal tissues. Biol Chem 1957, 226:497-509

18. Zilversmit DB and Shea TM Quantitiation of apoB48 and apoB 100 by gel scanning or radio-iodination. J Lipid Res 1989 30:1639-1646

19. Davis RA, Trift RN, Wu CC and Howell KE Apolipoprotein B is both integrated into and translocated across the endoplasmic reticulum membrane. Evidence for two functionally distinct pools. J Biol Chem 1990, 265:1005-1011

20. Furukawa S, Sakata N, Ginsberg $H N$ and Dixon JL Studies of the sites of intracellular degradation of apolipoprotein $B$ in HepG2 cells. J Biol Chem 1992, 267:22630-22638

21. Dashti N The effect of low density lipoproteins, cholesterol, and 25-hydroxycholesterol on apolipoprotein $B$ gene expression in HepG2 cells. J Biol Chem 1992, 267:7160-7169
22. Cianflone KM, Yasruel Z, Rodriguez MA, Vas D and Sniderman AD Regulation of apoB secretion from HepG2 cells. Evidence for a critical role of cholesterol ester synthesis in the response to a fatty acid challenge. J Lipid Res 1990, 3 I :2045-2055

23. Tanaka $M$, Jingami $H$, Otani $M$, Cho $M$, Ueda $Y$, Arai $H$, Nagano $Y$, Doi $T$, Yokode $M$ and Kita $T$ Regulation of apolipoprotein $B$ production and secretion in response to the change of intracellular cholesterol ester content in rabbit hepatocytes. J Biol Chem 1993, 268: |27|3-127|8

24. Watts GF, Naoumova RP, Kelly JM, Riches FM, Croft KD and Thompson GR Inhibition of cholesterogenesis decreases hepatic secretion of apoB I00 in normolipidemic subjects. Am J Physiol 1997, 273:E462-E470

25. Burnett JR, Wilcox LJ, Telford DE, Kleinstiver SJ, Barett PHR, Newton RS and Huff MW Inhibition of HMG-CoA reductase by atorvastatin decreases both VLDL and LDL apolipoprotein B production in miniature pigs. Arterioscler Thromb Vasc Biol 1997 , I 7:2589-2600

26. Sniderman $A D$ and Cianflone $K$ Substrate delivery as a determinant of hepatic apoB secretion. Arterioscler Thromb Vasc Biol I993, 13:629-636

27. Pal S, Santos C, Ho N, Allister E, Dubois P, Mamo J and Croft K Red wine polyphenolics increase the low density lipoprotein receptor and suppress the secretion of apoB 100 in human HepG2 Cells. J Nutrition 2002,

28. Bursell C, Roach PD and Pal S Green Tea upregulates the LDL receptor through sterol regulated element binding protein in HepG2 cells liver cells. J. Agr and Food Chem 200 I, 49(I I ):5639. 5645

29. Hussain MM, Kanch RK, Zhou Z, Luchoomun J, Zu H and Bakillah A Chylomicron assembly and catabolism: role of apolipoproteins and receptors. Biochim Biophys Acta 1996, I 300:151-170

30. Paulweber $B$ and Levy-Wilson $B$ The mechanism by which human apolipoprotein $B$ gene enhancer and reducer interact with the promoter are different in cultured cells of hepatic and intestinal origin. J Biol Chem I99I, 266:24I6I-24I68

3I. Pau E, He Y, Lougheed M and Steinbrecher UP Inhibition of hydroxymethylglutaryl coenzyme $A$ reductase activity does not affect the secretion rate of apolipoprotein $B$ and $A$ I by CaCo2 cells. Biochem Cell Biol 1995, 73:81-90

32. Shurtleff, William and Akiko Aoyagi The Book of Kudzu: A Culinary and Healing Guide. Garden City Park, NY: Avery Publishing Group.

33. Bell C, Ritchie C and Wilson CR The Kudzu File. The Encyclopedia of Southern Culture. University of North Carolina Press 1989

\section{Pre-publication history}

The pre-publication history for this paper can be accessed here:

http://www.biomedcentral.com/1472-6882/2/12/prepub

Publish with Bio Med Central and every scientist can read your work free of charge

"BioMed Central will be the most significant development for disseminating the results of biomedical research in our lifetime. "

Sir Paul Nurse, Cancer Research UK

Your research papers will be:

- available free of charge to the entire biomedical community

- peer reviewed and published immediately upon acceptance

- cited in PubMed and archived on PubMed Central

- yours - you keep the copyright
BioMedcentral 